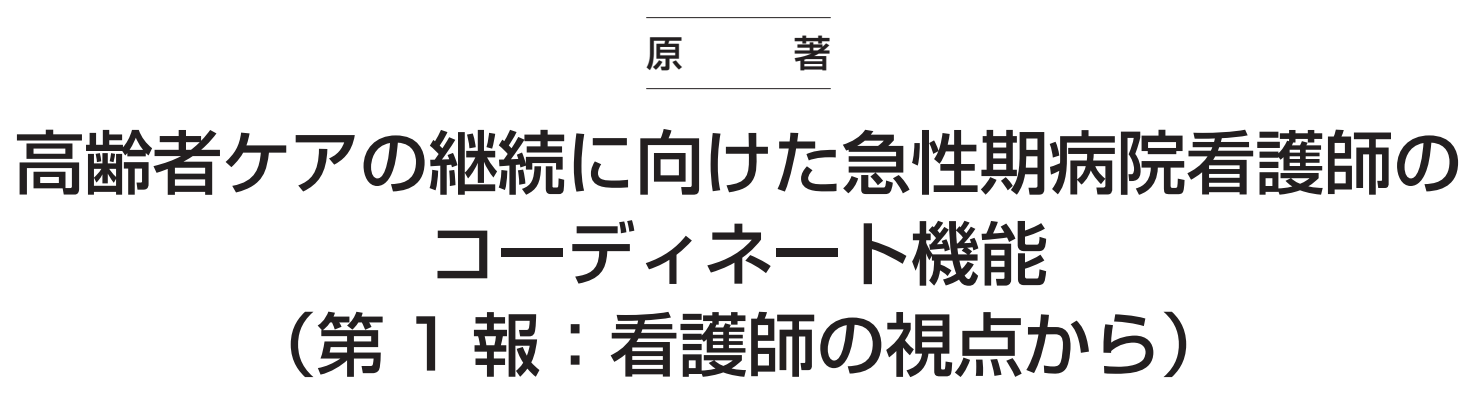

\title{
Nursing Actions in Acute Care Hospital Settings to Continue with Care for Elderly People (Part 1: Nurses' Perspective)
}

大原裕子 ${ }^{1)}$, , 河井伸子 ${ }^{2)}$, 黒田久美子 ${ }^{1)}$, 坂本明子 ${ }^{3)}$, 石井優香 ${ }^{4)}$, 正木治恵 ${ }^{1)}$

Yuko Ohara, Nobuko Kawai, Kumiko Kuroda, Akiko Sakamoto, Yuka Ishii, Harue Masaki

キーワード : 移行ヶア, 高齢者, ケアの継続, 連携

Key words : care transition, elderly people, continuity of care, collaboration

\begin{abstract}
Aim: This study aimed to identify actions that nurses take in acute care hospital settings to continue with care for elderly people.

Method: Sixteen nurses participated in semi-structured interviews. Interview data were analyzed using a qualitative synthesis method (KJ method) and then organized into groups representing the targeted nursing actions.

Results: The following six actions were extracted from the interview data. 1) Encourage your healthcare professional team to pay attention to elderly people's hopes or values based on their everyday interactions. 2) Encourage collaboration between healthcare professionals by sharing information about elderly people from multiple perspectives and discussing possible treatments. 3) Gain a foothold for elderly care by respecting their own way of living and ensuring other healthcare professionals consider elderly people as human beings. 4) Gain a foothold for healthcare professionals' work by respecting individual specialties and determining their area of responsibility. 5) Control the environment around elderly people by supporting caregivers, adjusting the relationship between an elderly person and his/her caregiver and informing general citizens. 6) Control the environment around healthcare professionals by creating a system to communicate smoothly.

Conclusions: Actions 1) and 2) represent "Encouraging", actions 3) and 4) represent "Gaining a foothold" and actions 5) and 6) represent "Controlling the environment". Furthermore, actions 1), 3) and 5) targeted elderly people and actions 2), 4) and 6) targeted healthcare professionals. Therefore, we found two axes of nursing actions: "Encouraging-Gaining a foothold-Controlling the environment" and "Elderly people-Healthcare professionals".
\end{abstract}

受付日：2019年 4 月 4 日受理日：2019年 9 月 5 日

1) 千葉大学大学院看護学研究科 Graduate School of Nursing, Chiba University 2) 大阪大学大学院医学系研究科 Graduate School of Medicine, Osaka University 3) 千葉県立保健医療大学健康科学部 Chiba Prefectural University of Health Sciences 4$)$ 千葉大学大学院看護学 研究科博士後期課程 Doctoral course, Graduate School of Nursing, Chiba University

*E-mail: oharayuko@chiba-u.jp 


\section{要旨}

目的：高齢者ケアの継続に向けた急性期病院看護師のコーディネート機能を明らかにする.

方法：看護師 16 名を対象に半構成的面接を行い質的統合法（KJ 法）にて分析した。

結果 : コーディネート機能は,【他職種を含めたケア実践への動力：日頃の関わりから高齢者の望みや 価值観を感性で捉え支える】, 【他職種との連携・調整への動力: 多角的視点での情報収集・現状判断と 予測からの舵取り】, 【高齢者の生き様を尊重したケア実践に向けた足固め: 高齢者の全体像やケアの方 向性一致・集約への働きかけ】, 【よりょい連携に向けた足固め：互いの専門性の尊重と担当領域の見定 め】, 【高齢者をとりまく環境に対する調整 : 介護者へのケアや関係調整, 地域住民への啓発】, 【システ ム環境に対する調整：伝達をスムーズにする為の手段やルートの構築】の6機能であった.

結論：コーディネート機能は「足固め一動力ー調整」と「高齢者一他職種」からなる 2 軸構造となった.

\section{I .はじめに}

政府は，超高齢社会に向けた政策として，医療機能 の分化・強化ならびに，医療機関間あるいは医療・介 護施設間の役割分担と連携による効率化，地域包括ケ アシステムの構築を推し進めている（厚生労働省, 2017). 今後, 複数の疾患や障害を併せ持ち生活する高 齢者を，地域や在宅が中心となって支える傾向は強ま るとみられている. 多くの高齢者は複数の疾患を抱元, 入退院を繰り返している。身体状態とそれに応じた生 活状況の変化を繰り返す高齢者は, 自ずと病院, 施設, 在宅など治療や療養の場を行き来することになる。こ うした高齢者の特徴を踏まえると, 高齢者が安心して 一定した質の担保されたケアを受け続けるには，それ ぞれの場の保健医療福祉に携わる人々を結んでいく看 護師のコーディネート機能が支援の要となる。

現在，病院では，退院支援部門に所属する看護師や 退院調整を担う看護師が, 治療・療養の場の移行にお けるコーディネート機能を専門的に担っている。しか し，日常的に高齢者や家族と関わっているのは，こう した専門部署に属しない, 病棟や外来の看護師である。 坂井（2015）は「病棟看護師が退院支援に関する能力 を身につけ，退院調整部署と病棟の効果的な協働シス テムを確立していくことが必要」と述べている．また， 早い段階から退院後を見据えて関わる重要性から, 平 成 30 年度診療報酬改定では入院予定の患者に対する 入院前からの支援が評価されることになった（厚生労 働省，2018）。したがって, 病棟や外来に所属する看護 師にはコーディネート機能を発揮し，治療・療養の場 の移行を円滑にするような支援が期待されていく．特 に地域で拠点となるような急性期病院は治療や療養の 変化が生じる転機の場であることから, 多様なコーディ ネート機能を必要とすると考えら机る。
戸村ら (2013) は，退院支援看護師の実践能力を評価 するための尺度を開発しているが，対象は退院支援部 署に所属し退院支援業務を主とする看護師であり, 病 棟や外来に所属する看護師は含んでいない。 また，こ の尺度ではコンピテンシーを理論的基盤におき「退院 支援のプロセス」と「病院内外のスタッフとの連携」を 枠組みに構成し職務行動を示しているが，両者の構造 は示されておらず，対象となる患者像も特定はしてい ない，臨床現場では，各病棟・外来ごとに退院支援を 担う看護師を配置したり（山田，2012）, 病棟看護師を 対象に退院支援・調整に関する研修を実施する施設が 現れてきており（岡田ら，2016），退院支援や在宅療養 移行支援における看護師の看護実践内容も報告されて いる（大森ら, 2015 ; 品川・黒田, 2017 ; 長嶋, 2017). さらに, 病棟看護師を対象とした研修プログラムが作 成され退院支援にあたって行うべき支援内容が示され， それがどの程度実施されたのかの評価尺度も開発され ている (坂井, 2015). Jeffs et al. (2017) は，「患者・家 族・ケア提供者に対するセルフマネジメントスキルに 関する教育」等 11 の効果的な看護師主導の移行支援内 容を特定している。しかし, 高齢者ケアが継続される よう他職種・他機関との連携において, 病棟や外来の 看護師がそれらの支援内容をどのように実践している のか，そして支援内容の実践においてどのような㗢き を担っているのかといった，果たしている機能につい ては明らかにされていない。このコーディネート機能 を明らかにすることは，その支援内容が何に繋がり,ど のような意味をもつのかを示すことに貢献すると考え る。また，地域保健や社会福祉領域において用いられ る「ケアマネジメント」ケアコーディネーション」が， ケア対象者にとってサービスの種類・程度が最適かぞ うかを判断し適切な時期に総合的に提供されるよう, 主としてサービスの調整を行うものであるのに対し (平 
野, 1997), 本研究でのコーディネート機能はサービス の調整に留まらず，病棟や外来の看護師が，高齢者ケ アを継続できるよう看護実践しながら，看護師と他の 専門職とのコーディネート，他の専門職間のコーディ ネートをしていることに着目したものである。この多 岐にわたる働きを明らかにすることは，病棟や外来看 護師の看護実践の意味を導くものとして重要である.

そこで, 本研究では高齢者ケアの継続に向けた急性 期病院看護師のコーディネート機能とその構造を, 看 護師自身の実践内容に基づいて明らかにすることを目 的とした.

\section{II . 用語の定義}

\section{1. コーディネート機能}

コーディネーションに関する文献（鈴木ら，2013； 日本看護協会，2007）を参考に，「コーディネート機 能」を「高齢者がよりよく生活を送ることができるよ うにする為, 異なる専門職の立場や役割の特性を引き 出し調和させ, それぞれが効果的に機能しつつ, 同じ 目標に向かって全体の取り組みが有機的, 統合的に行 えるように，高齢者への働きかけも含んだ環境を整え る働き」と定義する。

\section{III. 研 究 方 法}

\section{1. 研究対象者}

研究対象者は, 地域の拠点となる急性期病院に所属 している看護師とした，複数の疾患や障害を併せ持つ 高齢者が急性期病院の病棟や外来から療養の場が変化 するにあたり，他の専門職と連携し必要なケアを継続 できるよう援助をおこなつた経験をもつ看護師として, 対象施設の管理者から推薦を受けた者とした。専門看 護師などの資格や職位は問わないが，退院支援・調整 の専門部署に所属する看護師は除外した。なお，対象 施設は, 連携の多様性を考慮し, 都市部と地方にある 急性期病院を含むようにした。

\section{2. データ収集期間}

2015 年 11 月～2016 年 7 月

\section{3. データ収集方法}

都市部 3 施設，地方 3 施設それぞれに所属する看護 師に協力を依頼し, 静かで落ち着いた雾囲気の個室を
選定し, 安寧や職務遂行に悪影響がないよう対象者の 都合のよい時間や場所を確認して，1名 30〜60 分程度 で半構成的面接を実施した。対象者には，他部署や他 施設，他職種と連携することにより必要なケアを継続 できた看護実践について, 高齢者が抱える問題の背景, 援助行為や他職種との連携活動とそのプロセスや手段, 評価について語ってもらった。 その際, その他職種を 連携先として選んだ理由, その行為・活動を行おうと 思った理由や感じたり考えたことについても尋ねるよ うにした。面接内容は同意を得て録音し逐語録にした。

\section{4. データ分析方法}

高齢者ケアにおいて関与する変数は多様であり複雑 に関連し合っている。本研究では, こうした複雑な現 象の中で，予規定された分類枠を当てはめるのでは なくデー夕のもつ意味を純粋に取り出すことでコーディ ネート機能を明らかにしようとすることから, 現象の 断片であるデー夕群から統一した全体像をあらわすこ とができる質的統合法（KJ 法）を用い（山浦，2012） 分析した．分析手順は, まず逐語録の内容を繰り返し 読み,「高齢者ケアの継続に向けた他職種との連携にお いて果たしている看護師のコーディネート機能はどの ようなものか」という視点で単位化し，1つのラベル は 1 つの志を示す文章とした。 次に, 相対的に類似す るもの同士のラベルを集め, 集まったラベルの全体感 を表すような一文を表札としてつけた。同様の手順で ラベル集め, 表札づくりのグループ編成を繰り返し, これ以上集まらなくなった段階の表札を最終ラベルと した，最後に，最終ラベルを用い，そのラベル間の関 係性に着目してラベルを配置し, ラベル同士の関係を 記号と添え言葉で表し，その内容を端的に示すシンボ ルマークをつけ空間配置図とした。分析は質的統合法 （KJ 法）に精通した研究メンバー 3 名で行い分析の妥 当性に努めた。

\section{5. 倫理的配慮}

千葉大学大学院看護学研究科倫理審査委員会の承認 を得た後 (承認番号 27-40), 対象者に研究目的と方 法, 匿名性の保持と個人情報の保護, 研究参加への自 由意思ならびに途中辞退の保障，またその場合も不利 益を生じないことについて, 書面と口頭で説明したう えで書面にて研究参加の同意を得た。研究の全過程に おいて, 研究参加の任意性, 匿名性, 安全性を確保し, 得られたデー夕は厳重に管理した。 


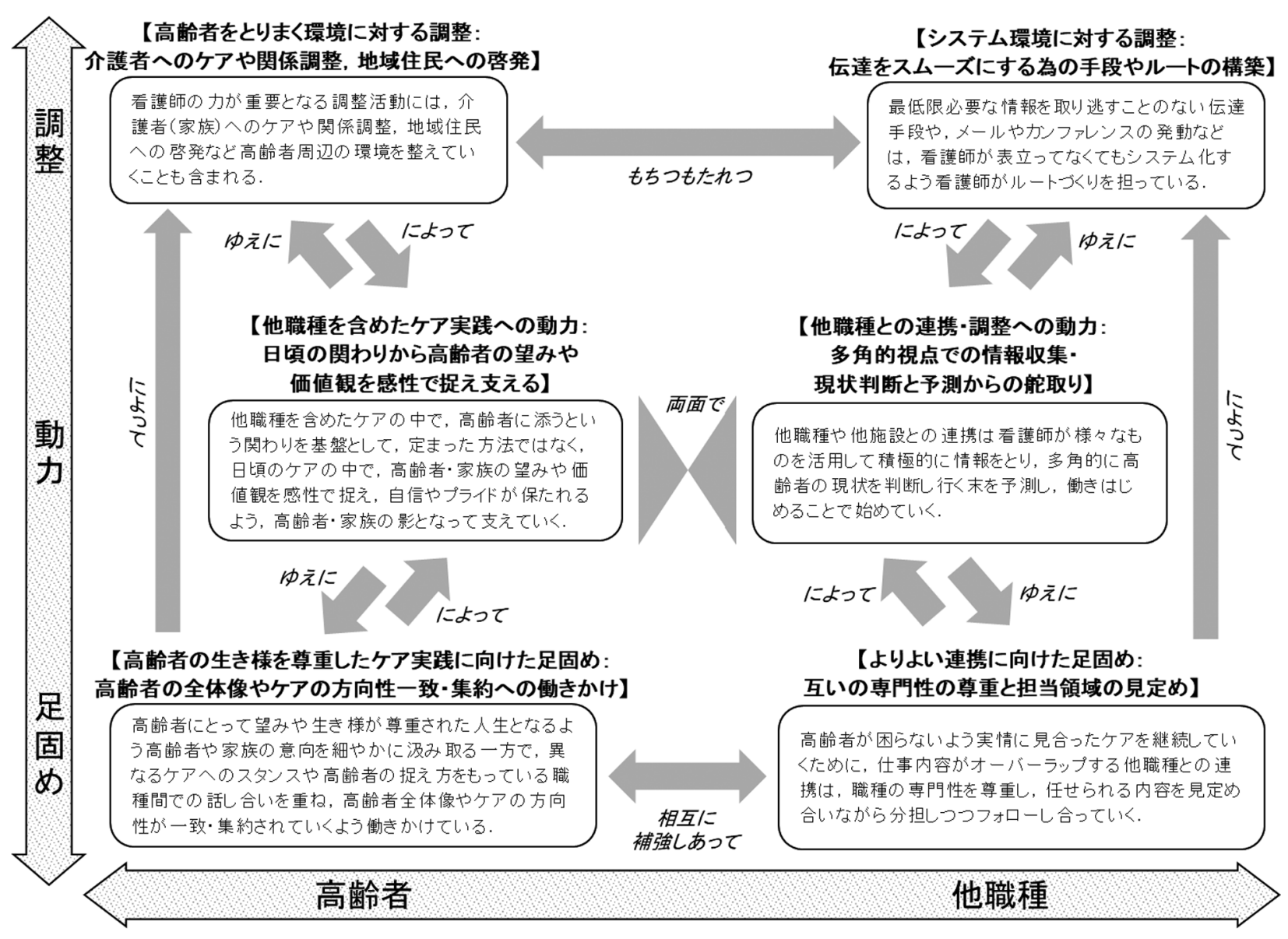

図 1 高齢者ケアの継続に向けた急性期病院看護師のコーディネート機能

\section{N. 結 果}

\section{1. 対象者の概要}

対象者は，都市部 3 か所，地方 3 か所の急性期病院 に所属している看護師 16 名であり, 内訳は外来/病棟 副看護師長 9 名（うち，1 名はインタビュー時に副看 護部長となったが研究依頼時ならびに語られた内容は 副看護師長時のもの), 外来/病棟看護師 6 名, 看護部 所属看護師 1 名であった。このうち, 慢性疾患看護専 門看護師の資格を有する者は 2 名, 老人看護専門看護 師の資格を有する者は 2 名であった。年齢は，22～ 55 歳 (平均 $39.8 \pm 8.4$ 歳), 看護師としての経験年数は, 3〜32 年 (平均 $16.4 \pm 8.0$ 年) であった. インタビュー 回数は各対象者 1 回で, 時間は 54 92 分間 (平均 69.3 \pm 11.4 分間）であった.

\section{2. 分析結果}

分析には全対象者のラベル 299 枚を用い, 多段ピッ
クアップ法（山浦，2012）にて 155 枚となったラベル を 7 段階に渡ってグループ編成を繰り返し, 最終的に 6つのシンボルマークとなった。 なお，文中の【】 はシンボルマーク，［］は最終ラベル，「」はロー データを示す，以下，空間配置図について説明したの ち，6つのシンボルマークごとに説明する.

1）看護師のコーディネート機能の空間配置図

看護師のコーディネート機能には 2 つ軸が存在し た（図 1).

1 つは, 高齢者ケアの継続と, それに向けて他職種 と連携するための「足固め」，それを土台とした「動 力」, そしてさらに看護師から他職種あるいは高齢者周 囲へと拡張させていく「調整」といった「足固め一動 力一調整」機能からなる軸である。「足固め」は, 他職 種との【よりよい連携に向けた足固め】である【互い の専門性の尊重と担当領域の見定め】機能と【高齢者 の生き様を尊重したケア実践に向けた足固め】である 
【高齢者の全体像やケアの方向性一致・集約への働きか け】機能で,これらは相互に補強し合っていた。「動 力」は，【他職種を含めたケア実践への動力】である 【日頃の関わりから高齢者の望みや価値観を感性で捉え 支える】機能と【他職種との連携・調整への動力】で ある【多角的視点での情報収集・現状判断と予測から の舵取り】機能を両面とし中核となった。「調整」で は, 看護師は【システム環境に対する調整】である【伝 達をスムーズにする為の手段やルートの構築】機能と 【高齢者をとりまく環境に対する調整】である【介護者 へのケアや関係調整, 地域住民への啓発】機能を担い, これらも相互に補い合う関係であった。

もう 1 つの軸は，「高齢者」に向けた視座と「他職 種」に向けた視座からなる「高齢者一他職種」それぞ れを中心に働きかける機能の軸である。これには，【高 齢者の生き様を尊重したケア実践に向けた足固め: 高 齢者の全体像やケアの方向性一致・集約への働きか け】が【他職種を含めたケア実践への動力：日頃の関 わりから高齢者の望みや価值観を感性で捉え支える】, 【高齢者をとりまく環境に対する調整：介護者へのケア や関係調整, 地域住民への啓発】へと繋がる,「高齢者 に対してぞうケアしていくか」といった視座と，【より よい連携に向けた足固め：互いの専門性の尊重と担当 領域の見定め】が【他職種との連携・調整への動力： 多角的視点での情報収集・現状判断と予測からの舵取 り】、【システム環境に対する調整：伝達をスムーズに する為の手段やルートの構築】へと繋がる,「他職種に 対してぞうアプローチしていくか」の視座が作る軸で あった。

2）6機能からなる看護師のコーディネート機能

（1）【他職種を含めたケア実践への動力：日頃の関わ りから高齢者の望みや価值観を感性で捉え支える】機能

これは, [他職種を含めたケアの中で, 高齢者に添う という関わりを基盤として, 定まった方法ではなく, 日頃のケアの中で高齢者・家族の望みや価値観を感性 で捉え, 自信やプライドが保たれるよう高齢者・家族 の影となって支えていく）というものである．看護師 は，時間がない中でも特別な関わりを通してではなく， 高齢者と何気ない普段の会話を通して関わりを持つよ う心がけており，会話の中にある高齢者の背景・望む あり方や体調の変化などを自然に把握しケアに繋げる ことを大切にしていた。そして, ささやかな変化であ れば見守り, 直感的にいつもと異なる様子を捉えて関
わるようにしたり，異変があれば他職種に発信したり していた。

「普段の会話を大事にすればよかった。（自宅に） 帰りたいか䚻りたくないかよりも，おうちの話とか 他愛もない話でキャッチしなきやいけない部分もあ りそうだった。 犬をどうしても最期見たいっていう のも，そういえば犬のこと言つてたよ㸚みたいなの をちらちら言う。それを何かそこに繋げていったり だとかする事の大事さを学べた.」

「毎回看護义モをしてるかっていうとそうじゃなく て，外来の待合に行って，『こんにちは，どう？』つ

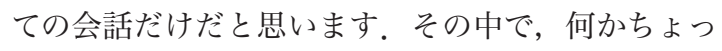
といつもより何か太ってたし, とか反応が悪かった みたいとか, ちょつと臭う补とか, いつもついてく る家族が今日はついてこなかつたねと。何かピンと きておかしいからちょっと呼んでみる.」

（2）【他職種との連携・調整への動力：多角的視点で の情報収集・現状判断と予測からの舵取り】機能

これは, [他職種や他施設との連携は看護師が様々な ものを活用して積極的に情報をとり, 多角的に高齢者 の現状を判断し行く未を予測し, 働きはじめることで 始めていくというものである. 看護師は, せん妄に なりそうか, フォロー上必要となるポイントは何か等, 高齢者の個々の状況に対応できるだけの疾患や治療経 過への視点をもち, 先を予測しながら, いかに情報を 得て, どの時期にどのようにして, どの他職種や他部 署に繋げていくかを見極めていた。一方で, 生活への 視点をもって, セルフケア能力や $\mathrm{ADL}$, 高齢者・家族 の思いや状況等ありとあらゆる側面から総合的に把握 し関連づけ，そのアセスメント内容を他職種に伝えて いた。

$\ulcorner$ (本人の清潔保持能力の見極めは) 本人の理解力, 普段の内服薬の管理とかの理解もそうですし, あと は手先の器用さとかそういうところ, あと清潔度合 いですね. 日ごろパンツとか污れていても気にしな いような人だったりするのかどうか, お風呂とかちゃ んと清潔に入れたりしているのかどうか, あと本人 に管理能力がいま一つかなと思っても，すごくょく やってく机る奥さんがいるとか........情報を先生 に伝えます.」

また，看護師は今後起こりうることを療養環境や病 状から統合して予測し, その先に備えるため, 他職種 や高齢者・家族が二の足を踏んでいるようなことであっ ても高齢者・家族が安心して次の展開にスムーズに進 
めるように，情報収集したりケアの方策を考えたり今 後関わることが予測される他職種が参入できるよう取 り計らったりして, 早めに手を打つ動きをしていた。 そして, 踏み出しにくいことであっても, 次の展開を 生む支援になると考元, 在宅療養に関係する人々に看 護師自らが積極的に交渉にあたったり，看護師が日々 の状態をみる中で，帰机そうだと見通せたタイミング で，他職種・家族に働きかけるようにしていた。

「入院した時に全く情報がないのは避けたいなって （中略）ある程度治療が効かなくなった段階で情報を 取っていく.」

「おそらく歩いて州れるだううというのは私の中で はあったんですが.（中略）お風呂だとか，この後 ADL の予後的なことを考えると改修しておいたほう がいいだろうなというような予測と（中略）介護保 険取れるかもしれないと, 地域連携にその辺りの事 情を話して (後略).」

「何が嫌で（サービスを）入れたくないのかとか, そういう部分を明らかにしないと先に進めないので 聞き，ご家族・本人ができるだけ具体的に想像がつ くように説明をして (後略).」

「何かあったらうちの病院にっていう関係性が（医 師と患者に）できていた中で，やはり最期を苦しめ ないっていうことを考えると（中略）往診の先生と か訪問看護を入れたりとか，していきましょうと.」

（3）【高齢者の生き様を尊重したケア実践に向けた足 固め: 高齢者の全体像やケアの方向性一致・集約への

\section{働きかけ】機能}

これは，[高齢者にとって望みや生き様が尊重された 人生となるよう高齢者や家族の意向を細やかに汲み取 る一方で, 異なるケアへのスタンスや高齡者の捉え方 をもつている職種間での話し合いを重ね, 高齢者の全 体像やケアの方向性が一致・集約されていくよう働き かけているというものである。看護師は, 高齢者に 残された時間の過ごし方については, 病状コントロー ルの視点を押さえつつも高齢者が大切にしていること を最優先に生きてきた背景を踏まえて病気と生活を結 び合わせ，家族や他職種とも合意のプロセスを歩みな がら，高齢者にとって良い人生であるようにコーディ ネートしていた.

「口から食べられるという所が命取りになることも 考えられるけども，グルメな人だから食べることを 最優先に考えて, それでも初期対応が遅くならない ように訪問看護と往診を入れるという所と，延命治
療はしないという所を取り決めて，今後本当にどう いうふうに医療を継続するかというのをお家で考え ていきましょうという体制を作った。」

特に, 必要な医療資源導入が難しかったり介護負担 が大きかったりする時や，高歯者の病状や治療方針， 療養が変化する時は, 家族と医療者それぞれのスタン ス・見解・価值観が一致せず難しい. しかし，看護師 は表面化していない高齢者や家族の生活や人生, 病気 の捉え方, さらに本当の希望や意向を引出し, 些細な ものであっても他職種と共有することを, 支援するこ との限界を検討するよりも大切にしていた。カカンファ レンスの中では高齢者の全体像を共有できるよう各職 種が持っている情報をバランスよく集約するように， 職種間で異なる情報が存在する場合には高齢者がどの ような人で現状はどうなのか事実に基づいて理解され ケアの方向性が共有されるように㗢きかけていた。

「価値と価值がぶつかってる状態じゃないですか. 娘さん（介護者）もすごく摇机ていて，おばあちゃ ん（患者）の気持ちすごく分かるんだけど, 最期ま でできるだけお家で過ごすことがその方の良い最 期っていうのになるとも思うんだけど，でももう無 理なのって言うところを, 患者さんにとって何が一 番いいのかっていうのを, 話し合おうって言って, カンファレンスを開こうと（看護師が）呼びかけま した.」

（4）【よりよい連携に向けた足固め：互いの専門性の 尊重と担当領域の見定め】機能

これは, [高齢者が困らないよう実情に見合ったケア を継続していくために, 仕事内容がオーバーラップす る他職種との連携は, 職種の専門性を尊重し, 任せら れる内容を見定め合いながら分担しつつフォローし 合っていくというものである. 看護師は仕事の範囲 が他職種とオーバーラップしており限定が難しく, 看 護師と他職種各々が異なる見解を持っているため任せ きりや任されきりにならない認識にしたいと考えてい た。そして, 退院後の在宅ケアや外来サポートを他職 種に委㸚られるかどうか見定めながら, 高齢者が困ら ないよう確実にケアが提供されるようにしていた。1 人で抱え込まず他職種の専門性・持ち味を尊重し, そ れが発揮されるよう任せつつも経過は自らフォローし ていた.

「本当にプロに任せるしかないですよね。（中略） これってこうなんだというのが分かってくるので自 分の知識にもなる，全部任せっ切りじゃなくて『そ 
れつてどうなの？』と聞いていると思います.」

（5）【高齢者をとりまく環境に対する調整：介護者へ のケアや関係調整，地域住民への啓発】機能

これは, [看護師の力が重要となる調整活動には, 介 護者（家族）へのケアや関係調整，地域住民への啓発 など高齢者周辺の環境を整えていくことも含まれる] というものである. 看護師は, 対象となる高齢者にと どまらず，介護者（家族）など高齢者にかかわる周囲 の人々の生活を整えることまで含めて調整していた。 たとえば，介護者（家族）に認知症があることを見い だして支援したり，介護者（家族）の介護保険申請を 支援したりしていた。 また，介護が限界まできていた り 1 人で抱え込もうとしていたりするような介護者 (家 族）の思いをそれとなく察知して伝えたり話し合う場 を設けたりと高龄者と介護者（家族）の間に入って両 者を橋渡したり, さらに地域住民に地域包括ケアにつ いて啓発しょうとしていた。

「とてもじゃないけど（妻を介護しなくてはいけな いので）自分は入院できない (中略), まだ（妻の) 介護保険とかそういった手続きも全くしてないと言 うので, 地域医療連携部に連絡をして, 奥さんのこ とをお願いして，本人は入院できるょうにした.」

「(地域包括ケアの) 制度はできたけど, 実際には 地域の準備が整ってなくて,さらに一般の方がわかっ ていないんです，特に田舎の過踈地の方とかは家族 も本人もずっとここで見てもらえるもんだと思って います。そういう人たちが安心して州ってもらえる のにはそういう啓蒙ですとか, 看護師の力がすごく 大事なんじゃないかな.」

（6）【システム環境に対する調整：伝達をスムーズに する為の手段やルートの構築】機能

これは, [最低限必要な情報を取り逃がすことのない 伝達手段や,メールやカンファレンスの発動などは, 看護師が表だってなくてもシステム化するよう看護師 がルートづくりを担っている）というものである. 看 護師は, 情報の量や質が充実していることだけでなく 最低限必要な情報を取り逃がさないことも重視してお り, その伝達方法をルール化, システム化していくよ うにしていた。 また, 情報共有シートの運用状沉を見 守ったりメールやカンファレンスの発動等自分が表に は出ない形で, 現場で生じる軋轢を看護師が他職種と のパイプ役になることで見守ったり関係をとりもった りしていた。

「病棟の看護師さんもやっぱりサマリーをタイム
リーに入れられないので, 例えば在宅物品を提供し なくちゃいけないような方, 地域医療連携部に介入 してもらって問題がある方に関してはID と名前だけ でいいので退院する時に外来に教えてくださいって 伝える.」

\section{V. 考察}

1. 2 つの座標軸によって構造化されたコーディ ネート機能

本研究において看護師のコーディネート機能は,「足 固め一動力一調整」機能からなる軸と,「高齢者一他職

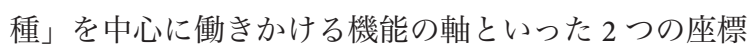
軸によって構造化できた。「足固め一動力一調整」機能 ではそれらが連動し，「足固め」が確実となってこそ 「動力」が効果的に機能し，そしてより幅広い「調整」 へと広がっていくものと捉えられた。また,「足固め一 動力一調整」機能からなる軸と,「高齢者一他職種」を 中心に働きかける機能の軸は 2 軸ともに, 高齢者ケア の継続に向けた他職種との連携には欠かせないが,「継 続」には「高齢者に対してどうケアしていくか」の視 座,「連携」には「他職種に対してどうアプローチして いくか」の視座が対応していると考えられた。つまり, 「高齢者に対してどうケアしていくか」の視座は高齢者 がその人らしく生きることを継続して支援するための 機能である一方,「他職種に対してどうアプローチして いくか」の視座は, 他職種に視野を広げ連携を活性化 する広角的な機能だといえる。つまり，ケアの「継続」 においては高齢者中心的であり，ケアの「連携」にお いてはその重点が他職種に移る。

瀧口ら（2013）は，人工呼吸器装着患者の管理にお いて看護師の多職種チーム機能を明らかにし,「日常性 最大化への挑戦」「個別性の反映」「多職種機能の統合」 「多職種機能の采配と強化」の 4 カテゴリーを調整の方 向性を示すものとしていた。この研究とは対象が異な るものの, 前者 2 カテゴリーは本研究の「高齢者に対 してどうケアしていくか」の視座に相当し, 後者 2 カ テゴリーは「他職種に対してどうアプローチしていく か」の視座に相当するといえる. 加えて, 本研究では 両者が複眼的視座をもつたコーディネート機能として 示されたことが特徴である。空間配置図の構造では, 「高齢者に対してどうケアしていくか」の軸と「他職種 に対してどうアプローチしていくか」の軸を対称に置 きつつも，それぞれの軸が「足固め一動力ー調整」へ 
し連動していくことから，6つの機能が別々に機能す るのではなく, 縦横無尽に各機能を関連し合わせて看 護師がコーディネート機能を発揮していたことを示す ものと考えられた。

\section{2. 看護師のコーディネート機能を明らかにするこ との意義}

1）過不足のないケアの提供にとどまらない, より 高齢者の目標を志向するケアの提供へ

退院支援・調整として行われている支援内容を明ら かにする研究はこれまでにも散見され，患者・家族の 意向確認, 医療処置・管理指導, 日常生活援助指導, 社会資源活用，他職種との連絡調整といった支援内容 が挙げられている（長嶋，2017；藤澤，2012）。こうし た支援内容の実践には，患者のありたい目標に向けて 看護実践しつつ他職種と連携していく看護師の働きが あり,その㗢き同士の構造を, 本研究ではコーディネー 卜機能として明らかにし可視化できた. Nosbusch et al. （2011）は，スタッフ看護師が効果的な退院支援を行う のを妨げる要素のひとつに「役割の混乱」をあげ，退 院支援のプロセスにおける他職種との関係において自 分達がどのように主導するのかスタッフ看護師の責任 として明確になっていないことを指摘している。療養 の場の移行における支援内容を実践しようとする時に, 全体の中でどこに位置づくコーディネート機能を駆使 しながら実践しているのかが明確となることは, スタッ フ看護師が役割を発揮する際の拠り所となると考える.

また，高齢者の療養の場の移行にあたって行う支援 は，その対象が必要としている支援内容を見出し，そ の状況に見合った社会資源を適用し，その人らしい生 活の継続を支えることが大きな目的である。しかし， 「移行支援の内容」を視点としてみていくと，ともすれ ば社会資源や医療処置, 自己管理方法の調整などが中 心となり，高齢者や家族に欠如あるいは不足している 部分を補うケアが移行支援だと捉えか放ない. そこで, 「移行支援のコーディネート機能」を視点にしてみるこ とによって，決して不足している部分を補うだけでは なく，高齢者や家族がぞう生きていきたいかという目 標を中心になされているものであることがわかり，そ れだけに留まらない支援の在り方がみえてくることが 期待される。佐久川ら（2009）は「回復期リハビリテー ション病棟看護師の在宅復帰支援についての認識と役 割」について調査しており，直接ケアや教育的ケアは 提供している一方で，家族または専門職種間の調整を
することへの認識が低かったことや調整機能そのもの への認識が高くないといった結果を示している。しか し, 研究対象である病棟看護師はカンファレンスの中 で患者の現状を説明したり患者の意思や希望の発言を 促すといった役割への認識は高いことが示されていた。 本研究結果を踏まえ机ば,こうした役割も看護師のコー ディネート機能のひとつであるといえ, 必ずしも直接 専門職と対応したり交渉したりする行為に看護師の コーディネート機能は限定されず，高齢者の在りたい 目標に近づけていくためにチーム内でなされる擦りあ わせ行為の中でも, その機能が発揮されていくと捉え ることができる。

\section{2）看護師のコーディネート機能の日常性}

高齢者の療養の場の移行支援においては, 看護師が チームの中での情報の源になっているという（Jeffs et al., 2018)．情報の源としての看護師の在り方は, 他職 種から看護師のところに情報が集まるというだけでな く, 看護師自身が高齢者の日常の中に存在しているこ とによって情報が集められるということが，【他職種を 含めたケア実践への動力】機能と【他職種との連携 · 調整への動力】機能の中で, 看護師が日常の何気ない 関わりや日頃の様子から情報を得ていたことから言え るだろう。高龄者の日常は看護師の日常でもある。高 齢者とその周囲には日々様々なことが生じているが, 高齢者の日常の場には看護師が存在しており, それは 特別に新たに設けた場ではない。例えば，他職種は高 齢者の思い等を聞き知るための設定や体制づくりから 始める必要があるかもしれない. しかし病棟や外来の 看護師は，高龄者の思いを聴くためにわざわざ面接場 面を設け情報を取りにいかなくても, 高齢者の情報を 肌で感じられる日常の場にいる. 本研究結果では, こ の㗢きは「動力」の機能の中に見い出されていた。こ のことは，日常の中でコーディネート機能が働いてい るからこそ「動力」となり得ていたのだと考えられる。 また，退院支援専門部署ではなく病棟や外来に所属し ている看護師の特徵を反映したものだといえ, このよ うな「日常性」の重要性を, 病棟や外来の看護師が意 識し，コーディネート機能として意味づけながら発揮 できると実践が深化していくのではないだろうか.

\section{3. 本研究の限界と今後の課題}

本研究では, 対象者の半数以上が副看護師長職であ り部署全体を見渡しコーディネート機能を発揮してい 
く力に長けていた可能性が高く, それゆえの結果であっ た可能性がある。しかし，複雑な高齢者ケアの継続に 向けた他職種との連携には，そうした高い実践能力が 必要であり，そのような能力を持った対象者から得ら れたコーディネート機能は，看護師の看護実践の質向 上に大いに役立てることができるだうう。今後は，本 研究で明らかになった知見に基づき，高齢者ケアの継 続に向けた他職種との連携において看護師がコーディ ネート機能を発揮しケアを実践できるようになるため のツールの開発につなげることが課題である。

付記 : 本稿は, 第 37 回日本看護科学学会学術集会にて発表 し，これに一部加筆修正を加えたものである.

謝辞：本研究にご協力いただきました皆様に心より感謝申 し上げます。本研究は JPJS 科研費 $15 \mathrm{H} 05284$ （研究代表者 正 木治恵）の助成を受けて実施した。

利益相反：本研究における利益相反は存在しない.

著者資格：YOは研究フィールドの調整, デー夕収集・分 析, 草稿の作成; NK はデー夕分析および草稿全体への助言 ; KK は研究フィールドの調整, デー夕収集, 草稿全体への助 言; AK はデー夕収集, YI はデー夕分析に貢献; HM は研究 の着想・計画, 研究フィールドの調整, 草稿全体への助言. すべての著者は最終原稿を読み, 承認した。

\section{文献}

藤澤まこと（2012）：医療機関の退院支援の質向上に向けた看 護のあり方に関する研究（第 1 部）一医療機関の看護職者 が取り組む退院支援の課題の明確化一, 岐皁看大紀, 12(1), 57-65.

平野かよ子 (1997) : ケアマネジメントとケアコーディネーショ ン，保健婦誌，53(12), 970-978.

Jeffs, L., Kuluski, K., Law, M., et al. (2017): Identifying effective nurse-led care transition interventions for older adults with complex needs using a structured expert panel, Worldviews Evid. Based Nurs., 14(2), 136-144.

Jeffs, L., Saragosa, M., Law, M., et al. (2018): The varing roles of nurses during interfacility care transitions, J. Nurs. Care Qual., 33(1), E1-E6.

厚生労働省（2017）：平成 30 年度診療報酬改定の基本方
針, Retrieved from: http://www.mhlw.go.jp/file/05-Shingikai12601000-Seisakutoukatsukan-Sanjikanshitsu_Shakaihoshou tantou/0000187616.pdf（検索日：2018 年 4 月 5 日）

厚生労働省（2018）：平成 30 年度診療報酬改定 個別改訂項目 について, Retrieved from: http://www.mhlw.go.jp/file/05Shingikai-12404000-Hokenkyoku-Iryouka/0000193708.pdf（検 索日：2018 年 4 月 5 日)

長嶋祐子 (2017) : 回復期リハビリテーション病棟の看護実践 一退院支援に焦点を当てて一, 昭和学士会誌，77(1),33-39.

日本看護協会 (2007) : 看護にかかわる主要な用語の解説, 11, Retrieved from: http://www.nurse.or.jp/home/publication/ pdf/2007/yougokaisetu.pdf（検索日：2018 年 4 月 5 日）

Nosbusch, J., Weiss, M., Bobay, K. (2011): An integrated review of the leterature on challenges confronting the acute care staff nurse in discharge planning, J. Clin. Nurs., 20(5-6), 754-774.

岡田麻里, 長江弘子, 谷垣靜子, 他（2016）：A 病院における 病棟看護師の退院支援・継続看護研修プログラムの学習成 果，日在宅ケア会誌，20(1), 63-71.

大森結美，田口敦子，加藤政子，他（2015）：慢性疾患患者の 退院後の療養生活からみた病棟看護師による退院支援内容 の検討, 東北大学医学部保健学科紀要, 24(2), 77-88.

坂井志麻 (2015) : 病棟看護師の退院支援能力の育成一教育プ ログラム運用の実際，宇都宮宏子，退院支援ガイドブック， 26-37, 学研プラス, 東京.

佐久川政吉，大湾明美，呉地祥友里，他（2009）：回復期リハ ビリテーション病棟看護師の在宅復帰支援についての認識 と役割, 沖縄看大紀, 10,35-43.

品川祐子，黑田寿美恵（2017）：終末期がん患者の在宅療養移 行に向けた看護師による退院支援に関する文献検討, 死の 臨, 40(1), 154-160.

鈴木薰, 鎌田雅史, 德山美智子, 他 (2013)：養護教諭のコー ディネーションと学校組織特性に関する研究 (第 I 報), 学 校保健研, 55, 140-152.

瀧口千枝，井上智子，佐々木吉子（2013）：人工呼吸器装着患 者の管理における看護師の多職種チーム調整機能の構造, 日クリティカルケア看会誌，9(3), 1-12.

戸村ひかり，永田智子，村嶋幸代，他（2013）：退院支援看護 師の個別支援における職務行動遂行能力評価尺度の開発, 日看科会誌, 33(3), 3-13.

山田佐登美 (2012)：地域医療連携システム『尾道方式』とケ アカンファレンス, Heart Nursing, 25(12), 80-87.

山浦晴男 (2012) : 質的統合法入門 考え方と手順, 医学書 院, 東京. 